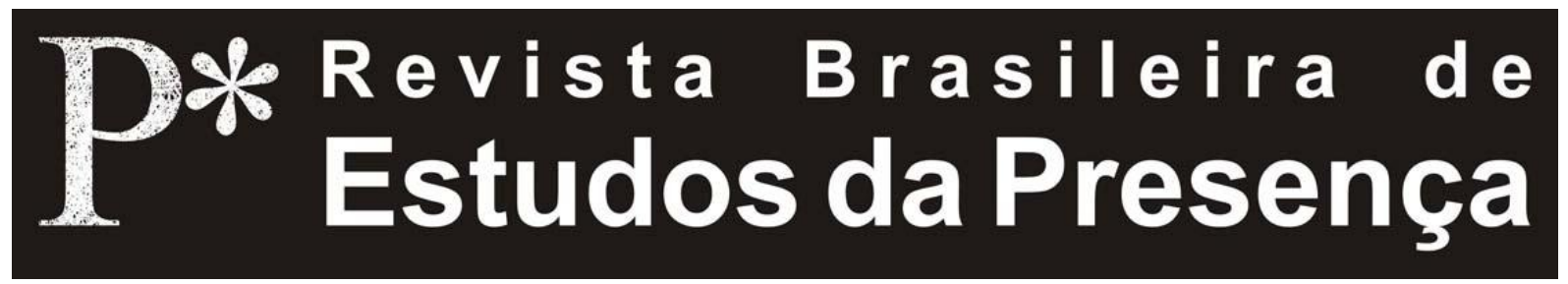

DOI - http://dx.doi.org/10.1590/2237-266021396

ISSN 2237-2660

\title{
O Ator Estrangeiro ou o Outro no Teatro
}

Georges Banu

Université Paris 3 - Sorbonne Nouvelle, França

\begin{abstract}
RESUMO - O Ator Estrangeiro ou o Outro no Teatro - Este artigo propõe uma reflexão sobre um fenômeno que, depois dos anos 1968, contamina progressivamente a cena europeia: o ator estrangeiro. Sintoma das mutações sociais - permeabilidade das fronteiras, maior liberdade linguística - , o ator vindo de longe acaba rompendo com o etnocentrismo que até então caracterizava o teatro. A partir dessa constatação, examina-se notadamente a formação dos grupos pluriétnicos, o plurilinguismo em cena e o uso que os encenadores fazem dele. Trata-se em seguida da questão do sotaque estrangeiro, dos efeitos produzidos na língua de acolhimento e da maneira como o público o percebe. Analisa-se isso levando em conta também a relação com o corpo estrangeiro, frequentemente utilizado como um elemento perturbador, ao trazer à cena uma nova corporeidade, uma presença e um engajamento diferentes. Por fim, aborda-se particularmente o percurso de dois atores vindos de longe: Sotigui Kouyate e Yoshi Oida.
\end{abstract}

Palavras-chave: Ator Estrangeiro. Língua. Sotaque. Dicção. Atuação.

ABSTRACT - The Foreign Actor or the Other in Theatre This article proposes a reflection on a phenomenon that, after 1968,has gradually contaminatedtheEuropean scene: the foreign actor. A symptom of social mutations - porosity of borders, greater linguistic freedom -, the actor comingfrom far away disrupted the ethnocentrism which until thencharacterized the theatre. From thisobservation, we examine the formation of multi-ethnic groups,multilinguism on stage and how directors make use of it. Then we dealwith the issue of foreign accents, their effects on the host languageand how thepublic sees it. This is analysed also

Georges Banu, O Ator Estrangeiro ou o Outro no Teatro.

R.bras.est.pres., Porto Alegre, v.1, n.2, p. 385-403, jul./dez., 2011.

Disponível em http://www.seer.ufrgs.br/presenca 
taking into considerationthe relation with the foreign body,frequently used as a disturbing element, by bringing to the scene anew corporality, a different presence and engagement. Finally, wediscuss the paths of two actors from afar: Sotigui Kouyate and Yoshi Oida.

Keywords: Foreign Actor. Language. Accent. Diction. Acting.

RÉSUMÉ - L'Acteur Étranger ou l'Ailleurs au Théâtre - Cet article propose une réflexion sur un phénomène qui, depuis les années 1968, «contamine » progressivement la scène européenne: celui de l'acteur étranger. Symptôme des mutations sociales perméabilité des frontières, plus grande liberté linguistique l'acteur venu d'ailleurs finit par briser l'ethnocentrisme qui caractérisait jusqu'alors le théâtre. Partant de ce constat, l'auteur s'interroge notamment sur la formation des troupes pluriethniques, sur le plurilinguisme au théâtre et les usages qu'en font les metteurs en scène. Il se penche par ailleurs sur la question de l'accent étranger, de ses effets sur la langue d'accueil et sur la réception qu'en fait le public. Son analyse prend également en compte le rapport au corps étranger, souvent utilisé comme agent perturbateur afin d'apporter à la scène une nouvelle corporalité, une présence et un engagement différents. Enfin, l'auteur s'attarde plus particulièrement sur le parcours de deux acteurs venus d'ailleurs : Sotigui Kouyate et Yoshi Oida.

Mots-clés: Acteur Étranger. Langue. Accent. Diction. Jeu.

A arte, no ocidente, está na sua particularidade, só funciona corretamente como um sistema aberto, capaz de integrar e de modificar os novos materiais $\mathrm{e}$ as informações recentes. Ao tomar emprestada a bela expressão de Valéry, deve-se admitir que toda cultura fechada é uma cultura ávida de poder ${ }^{1}$. A abertura aparece como indissociavelmente ligada à regeneração pelo abandono da centralização do poder. No teatro, como em toda parte, a questão do estrangeiro se coloca: o ator ou o espectador que eu sou. $\mathrm{O}$ ator estrangeiro vem acometer o etnocentrismo, sua unidade, sua dominação sobre o teatro. $\mathrm{E} \mathrm{eu}^{2}$, vindo de longe, sou talvez mais sensível a essa questão e gosto de me debruçar sobre ela.

\section{8 - A Grande Virada}

A constelação dos anos 1968 - tanto os anos que precedem o famoso e tão contestado mês de maio quanto

Georges Banu, O Ator Estrangeiro ou o Outro no Teatro.

R.bras.est.pres., Porto Alegre, v.1, n.2, p. 385-403, jul./dez., 2011.

Disponível em http://www.seer.ufrgs.br/presenca 
os que o sucedem - transforma as mentalidades em razão da multiplicação das viagens, da desagregação das fronteiras e do recurso a música e aos cantos. Uma nova liberdade linguística é adquirida em detrimento das línguas nacionais e em benefício de um diálogo para além das divisões habitualmente respeitadas. No teatro, fazendo referência, sobretudo, às teorias de Antonin Artaud, a prioridade é dada, por um bom número de grupos e de encenadores, especialmente ao corpo, à energia, à dimensão física com tudo o que ela comporta em termos de recursos plásticos e capacidades de homogeneização comunitária. O corpo é o novo elemento sociável. Peter Brook, sempre à escuta do espírito do seu tempo, do qual ele é o primeiro a apreender a emergência, cria, em Paris, seu Centro Internacional de Pesquisas Teatrais no qual a prioridade será conferida à improvisação e à comunicação não verbal. Ele se engaja, desse modo, naquilo que será tido como a sua mais radical pesquisa e que o conduzirá a Orghast, apresentado em 1971 em Chiraz. Brook, a partir do grego antigo, do latim, de uma língua ritual persa, Avesta, e de uma outra, imaginada pelo poeta Ted Hugues, reconstrói uma espécie de língua primitiva, língua das origens na qual o som predomina sobre a palavra. Aqui, se plurilinguismo existe, é para que ele seja integrado e ultrapassado em nome de uma unidade primordial, de uma língua desaparecida e reencontrada como um templo ressurgido das profundezas do oceano. Brook trabalha com o disparate e o sonoro a fim de alcançar um estado primeiro, a indiferenciação inicial. Essa aventura única, exemplar, terá, em seguida, um desenvolvimento visivelmente mais difundido graças à Trilogia Antiga, assinada por Andrei Serban. Nós estamos em 1968 e o heteróclito identitário é um desejo geral, como prova também a criação do Odin Teatret, no qual Eugenio Barba reúne atores, sobretudo nórdicos, da Suécia, Dinamarca, Noruega. No seu teatro, igualmente, o canto vai prevalecer sobre a língua e o gesto sobre a palavra. Nós somos os bárbaros dos tempos modernos, ele dirá, comunidades heteróclitas de atores que cruzam o mundo e afirmam seu plurietnismo como princípio refratário às

Georges Banu, O Ator Estrangeiro ou o Outro no Teatro.

R.bras.est.pres., Porto Alegre, v.1, n.2, p. 385-403, jul./dez., 2011.

Disponível em http://www.seer.ufrgs.br/presenca 
pertenças locais e regionais. Aqui ninguém é o estrangeiro do outro: utopia fundadora que se tornou efetiva no movimento internacionalista de 1968.

Brook afirma que existiu uma unidade inicial que foi em seguida fragmentada em benefício de uma multiplicidade racial e linguística cujas variações constituem, conforme a sua teoria, o arco-íris presente no mais profundo de cada ser. Ele mesmo, reunindo em sua equipe atores vindos de culturas e de línguas diferentes, mostra o esforço de reconstituição, no palco do teatro, do arco-íris que, implicitamente, se refere a essa unidade perdida, inicial, a unidade da essência. Ao discurso emancipado dos determinismos da história, Brook acrescenta um outro, complementar, secundário. Ele tem a ver com a atualidade e o presente, longe de toda utopia retroativa: ele concerne à cidade. Ele observa que a cidade grande moderna, as capitais, de Nova Iorque a Paris e Londres - triângulo mais frequentemente evocado -, se tornaram atualmente cidades impuras, cidades onde não se ouve mais uma só língua, mas uma multiplicidade de línguas, onde, se uma língua comum pode ser reconhecida, ela é manchada por sotaques diversos, ela é despedaçada, broken English, ela é rudimentar e instrumentalizada. O teatro, considera Brook, não pode ignorar essa mutação e seria absurdo, segundo ele, que a cena se erigisse como uma fortaleza inexpugnável de uma língua pura enquanto que tudo em torno atesta a sua desestabilização, suas fissuras e o seu desmoronamento. Ele proporá, a partir de 1974, espetáculos que, graças a elencos heteróclitos, integram e revelam essa impureza, sem, no entanto, instaurar um plurilinguismo cênico. Na época, a iniciativa brookiana se inscrevia num movimento mais abrangente e grupos como o Living, o Bread and Puppet e vários outros reivindicavam esse mesmo interesse pela heterogeneidade étnica. O princípio da identidade nacional não era mais de uso e no horizonte se desenhava a utopia comunitária. Alguns anos mais tarde, Ariane Mnouchkine vai adotar uma posição semelhante. Para ela, também, o elenco pluriétnico reflete o destino do mundo moderno, mundo que perturba os sedentarismos de outrora, mundo dos exílios, das partidas

Georges Banu, O Ator Estrangeiro ou o Outro no Teatro.

R.bras.est.pres., Porto Alegre, v.1, n.2, p. 385-403, jul./dez., 2011.

Disponível em http://www.seer.ufrgs.br/presenca 
forçadas, das errâncias. Os atores vêm de horizontes diferentes porque eles fogem de uma ditadura ou da miséria de uma guerra, eles trabalham com os atores franceses e, juntos, reconstituem o espectro contrastado do planeta dos destinos trágicos.

Ariane Mnouchkine, Brook e Barba acabaram constituindo juntos um verdadeiro triumvirat, pois, ultrapassando as escolhas de cada um, eles pretendem afirmar a dimensão plural, internacional do mundo atual. Em vez de uma unidade identitária, eles preferem a aventura coletiva de uma equipe a fim de que o conjunto predomine sobre o individual. A noção europeia de ator é atacada para erigir o palco como uma síntese da cidade assim como do planeta, no qual as fronteiras são questionadas e a diversidade cultural instaura seu reino. $\mathrm{O}$ ator estrangeiro é um sintoma dessa mutação radical. Aceitar o deslocamento da unidade nacional de uma equipe e integrar atores estrangeiros - eis o páreo da vanguarda que, em seguida, progressivamente, contaminará polemicamente a encenação europeia quase inteira.

Grupos pluriétnicos se constituirão em seguida por razões mais pessoais que, por sua vez, tomam a forma dos sintomas do mundo, de suas fraturas, de suas fricções. Citemos, por exemplo, o Naïf théâtre no qual Richard Demarcy, marcado pela lembrança de 1968, convoca mais de uma dezena de nacionalidades no seu grupo, ou o Teatro Malandro criado por Omar Porras, teatro no qual o diretor colombiano, instalado em Lausanne, reúne atores franceses e colombianos. $\mathrm{O}$ grupo se apresenta como um fotograma do líder que, sem jamais abandonar suas raízes colombianas, acabou se integrando na paisagem teatral francófona. Recentemente um coletivo alemão-israelense-palestino se constituiu para $\mathrm{o}$ espetáculo La troisième génération, cujo discurso se alimenta justamente da experiência pessoal dos atores reunidos. Em toda heterogeneidade de um grupo pode-se adivinhar uma visão de mundo e um programa de encenador. 


\section{O Plurilinguismo e suas Variações}

O grupo de Eugenio Barba, o Odin Teatret, circula muito pelo mundo, atravessa os continentes, encontra os públicos mais diversos. Barba e seus atores, antes da aparição das legendas que atenuam as dificuldades de compreensão de um texto, vão adotar uma espécie de bilinguismo para, justamente, integrar os espectadores, pois eles apresentam o espetáculo na língua original e, igualmente, na língua do país de acolhimento. Duas línguas se enredam, duas sonoridades dialogam e assim o espetáculo aparece como sendo um espetáculo de longe e daqui, um espetáculo em viagem internacional que se destina a um público local. É o que atesta a interpenetração das línguas, e o bilinguismo faz sobressair o duplo destino de uma representação, seu deslocamento e seu enraizamento. Inversamente, encontra-se um espetáculo como Romeu e Julieta, no qual, para ressaltar o conflito entre os Montecchios e os Capuletos, foram escalados atores palestinos $\mathrm{e}$ israelenses, atuando cada qual na sua língua. Esse confronto linguístico se constituía num dispositivo teatral que fazia pensar no conflito que abala o oriente médio, imagem atualizada do conflito de Verona. O uso do bilinguismo era motivado, dessa vez, por um imperativo dramatúrgico particularmente explícito. Nesse mesmo movimento se inscreve a opção de Emanuel MotaDemarcy que, para montar Trabalhos de amor perdidos de Shakespeare, sempre ele - dissocia linguisticamente o clã das mulheres e dos homens, escalando atrizes francesas e atores portugueses. Dois mundos, duas línguas. Na realidade, dessa vez se tratava de abordar literalmente, no palco, a fratura da qual a comédia shakespeariana trata. $\mathrm{Na}$ encenação de Sonho de uma noite de verão de Shakespeare, encomendada pela Union des Théâtres de l'Europe, escalou-se atores de vários países, permitindo a cada um a oportunidade de atuar na sua língua: isso deu origem a um espetáculo heteróclita que se atribuía um papel de representante dessa Europa plurilinguista, cuja diversidade era superada graças a esse autor unificador que ainda é Shakespeare, mesmo no mundo atual. Operação programática demais e sem uma 
verdadeira questão dramatúrgica em jogo. Assim, em cena, frequentemente, não se ouve mais o falar de uma nação somente, mas o da cidade atual, cidade cosmopolita. Cioran, que viveu em Sibiu, na Romênia, onde várias comunidades coexistem, já não dizia: eu não poderia viver numa cidade onde se fala uma só língua? Uma das razões da atração que Paris exercia sobre ele. Como sobre Brook.

\section{Sotaques Vindos de Longe}

$\mathrm{O}$ ator estrangeiro abre e enriquece o espectro sonoro da língua de acolhimento. Ela é perturbada, deslocada, tornada de certa maneira cubista, pois praticada por atores de origem diversa. Quem experimenta e venera o processo? A esse respeito a posição de Antoine Vitez foi exemplar. Ele foi o encenador que reabilitou o alexandrino em toda a sua beleza original, mas não procurou, no entanto, erigir seu teatro como museu da língua. Ele o assimilava mais a um laboratório da língua no qual atores franceses $\mathrm{e}$ estrangeiros deviam trabalhar, sempre na sua presença, na extensão do registro fônico, na variação dos ritmos, na miscigenação dos sotaques. Sotaques, como o meu ou o de seus colaboradores próximos, que ele gostava de ouvir e os quais ele enaltecia. Num pequeno texto, Le Cuisinier Holandais $^{3}$ ele declarava:

Se eu me interessei pelos sotaques estrangeiros, foi por uma preocupação maníaca com a língua, com a minha no caso. As pessoas que dizem com um sotaque estrangeiro belos textos franceses [...] me fazem reagir a minha própria língua: eu a ouço como falada de longe, eu a ouço melhor. Eu sempre fiquei maravilhado com as diferenças que os sotaques fazem aparecer na língua ela mesma. Quando, a um sotaque francês mais ou menos unificado, se misturam sotaques estrangeiros, se desfruta mais e melhor a língua?

É o homem que fala melhor a sua língua que admite, portanto, o falar do estrangeiro. Ele conhece a norma e, implicitamente, aprecia o desvio assim como ele desfruta da diferença. É ele que o avalia corretamente e o experimenta. E quase no mesmo espírito, um amigo

Georges Banu, O Ator Estrangeiro ou o Outro no Teatro.

R.bras.est.pres., Porto Alegre, v.1, n.2, p. 385-403, jul./dez., 2011.

Disponível em http://www.seer.ufrgs.br/presenca 
editor, alto responsável da Editora Gallimard ainda por cima, me confessava, confissão significativa: foi bonito, foi generoso, ouvia-se sotaques estrangeiros ${ }^{4}$.

No teatro, exceto casos excepcionais, não há plurilinguismo - atua-se numa só língua -, mas o pluriétnico flagrante no palco remete a um plurilinguismo fora da cena, o plurilinguismo dos atores reunidos nessa comunidade que atua no Bouffes $d u$ Nord ou na Cartoucherie de Vincennes, pois o francês que se ouve nos espetáculos de Brook ou de Ariane Mnouchkine é um francês colorido, ele registra as cores do mundo e, assim, ele se apresenta como portador, implícito, de um discurso político. O diretor que integra os sotaques estrangeiros na língua cessa de assimilá-la à expressão inalterável da identidade nacional; ele propõe outro universo sonoro, mais largo, polifônico, um universo múltiplo.

Mas se gosta de todos os sotaques, indiscriminadamente? De modo algum, pois a escuta, sobretudo num certo contexto histórico, não será indiferente à origem do sotaque. Assim como um sotaque local produz reações que dizem respeito às relações que o público mantém com uma categoria social ou uma região bem precisa, o sotaque estrangeiro engendra reações ligadas ao efeito que suscita em cena, esse lugar da Nação, a presença de outra nação. A recepção de um sotaque estritamente identificado depende da ligação que o público conserva com a cultura e a história de um povo, que o corpo do ator, para além do papel, ressalta em cena. Em Paris, nos anos 1930, Elvire Popesco não somente cultivava seu sotaque romeno, mas ela o fazia passar seguido por russo, aproveitando assim o capital de simpatia do qual beneficiava a colônia de russos brancos nessa época. Colônia de emigrantes, de sem-retorno, colônia de perdedores. Em Bucareste, ao contrário, nos anos 1950, quando o exército soviético ocupava o país depois de ter imposto o poder comunista, o sotaque russo de uma atriz, das mais militantes e fortemente engajadas na política oficial, era percebido por todos como uma prova suplementar da servidão do país. Era o sotaque do ocupante, um sotaque alemão não teria provocado $\mathrm{o}$ mesmo efeito numa cena parisiense nos anos 1940? Há

Georges Banu, O Ator Estrangeiro ou o Outro no Teatro.

R.bras.est.pres., Porto Alegre, v.1, n.2, p. 385-403, jul./dez., 2011.

Disponível em http://www.seer.ufrgs.br/presenca 
um determinismo contextual na percepção do sotaque.

Nas encenações de Antoine Vitez ouviam-se sotaques árabes, poloneses, gregos, nas de Ariane Mnouchkine privilegia-se os sotaques sul-americanos. Através dos sotaques, o espectador consegue detectar as afinidades eletivas do encenador, suas áreas culturais privilegiadas, seus interesses e suas indiferenças. Ao ator chileno, Andrés Perez Aroyo, que interpretava ZhouEnlai no Sihanouck, Ariane Mnouchkine pediu não para apagar o seu sotaque, mas para torná-lo não localizável. O sotaque deveria designar somente o estrangeiro, esse ator errante, sem documentos nem carteira de identidade, que foge das ditaduras em nome do seu métier. A confrontação com a língua aparece assim como uma imagem da condição do ator, do seu exílio, na maioria das vezes involuntário. $\mathrm{O}$ ator que vem de longe, o ator das origens longínquas.

Ao contrário, os encenadores tchecos, romenos que trabalharam em Paris, de Strehler à Krejca ou Pintilié ${ }^{5}$, nunca gostaram ou admitiram os sotaques estrangeiros. Suas bases linguísticas são mais fracas e eles têm necessidade de se apoiar sobre a terra firme da língua do país de asilo. Eles parecem mais com Cioran, já evocado, o Romeno que escreveu o francês mais puro ou a Kundera, que escreve o francês mais preciso. É o estrangeiro que acaba se posicionando como guardião do templo.

\section{A Luta ou o Jogo com a Língua}

$\mathrm{O}$ ator estrangeiro em cena mostra a luta com a língua a investir, a conquistar. $\mathrm{O}$ combate, quando $\mathrm{o}$ ouvimos em cena, produz o célebre Ostranienii Efekt, o efeito de estrangeirização do qual falava Chklovski: seu objetivo é de aguçar a percepção tornando o real diferente, estranho, inabitual. Bruce Myers, no Timão de Atenas dirigido por Peter Brook, mostrava a relação conflituosa que mantinha um ator da Royal Shakespeare Company com a língua e, na energia da sua atuação, o público reconhecia tanto o discurso de um general autocrata quanto o ranger de um cara a cara linguístico, verdadeiro corpo a corpo entre o francês e o inglês. Um

Georges Banu, O Ator Estrangeiro ou o Outro no Teatro.

R.bras.est.pres., Porto Alegre, v.1, n.2, p. 385-403, jul./dez., 2011.

Disponível em http://www.seer.ufrgs.br/presenca 
como o outro se tornavam estrangeiros. E assim o ator ia além do papel.

Uma outra observação merece ser adicionada: a percepção da relação do ator estrangeiro com a língua não se produz de maneira indiferente. Assim, aprecia-se Bruce Myers em Shakespeare, mas ele se exaspera em Racine, no qual a distância entre os limites do ator em termos de francês e as exigências do texto se revelam importante demais (um caso similar faz pensar no trabalho de Jean-Louis Martinelle com atores árabes, admiráveis num texto contemporâneo, mas problemáticos em Berenice). Da mesma maneira, ficamos maravilhados com Sotiguy Kouyate no Bishma do Mahabbarata, mas deploramos sua utilização rudimentar da língua em Próspero. Bishma, o sábio, descobria-se; Próspero, já se conhecia. Um nos era estrangeiro, o outro muito próximo. Nós escutávamos as palavras do poema indiano pela primeira vez; os monólogos de Próspero, entretanto, nós os sabemos de cor. Nesse interstício se passa algo fundamental para a recepção do sotaque estrangeiro. Sua ressonância depende de um saber e de um contexto.

De origem inglesa, David Warrilow levava à perfeição a coexistência dessas duas instâncias linguísticas, o inglês e o francês, mas por trás do seu francês ressoava sempre, clandestinamente, o eco longínquo da língua materna. Como uma fonte nem um pouco seca. Andrzej Sewerin, vindo de Varsóvia, luta com a língua e permite ouvir hoje uma das articulações mais fortes do francês, nobre, escultural, mas ainda cruzada com um leve sotaque polonês. Tudo neles demonstra uma relação viva entre uma língua de chegada que eles conquistam no dia a dia e a persistência de uma língua de origem que sobrevive ainda. Coexistência das línguas, coabitação das referências.

A relação de incerteza linguística pode suscitar um efeito de sedução que certas atrizes buscam graças à persistência do sotaque, assim como ao uso aproximativo da língua. Eles designam a bela estrangeira, a mulher de origem improvável, a mulher sempre em condições de partida. Jane Birkin ou Anna Prucnal não lutam com a língua, elas a tratam com desenvoltura, com graça, a fim 
de escapar da prosa do esforço. Nós não somos daqui, dizem elas, seduzindo.

Se o combate ou o jogo com a língua de acolhimento intervêm legitimamente em cena, a degradação da língua só pode perturbar. Quando a forma se desfaz em pedaços, quando o espectador não vê e não ouve nada mais do que um estrangeiro no sentido literal do termo, há uma perda textual, uma confusão no sentido, enfim, um desprazer. Isaach de Bankolé na Solidão dos campos de algodão de Koltès, encenada por Patrice Chéreau (primeira versão) tornava $\mathrm{O}$ francês incompreensível e, assim, o que deveria ser, originalmente, um diálogo filosófico naufragava em um magma de balbuciamentos. O espectador, consternado, acabava sendo testemunha de um naufrágio da língua. Ao correr o risco de chocar, tomando-se emprestado um termo frequentemente contestado, pode-se admitir que há um limite de tolerância linguística, além do qual o prazer da escuta cessa e a comunicação se interrompe. A reapresentação do papel por Chéreau deve seu sucesso tanto à performance do ator quanto à reabilitação da língua. É a carência frequentemente criticada em certos atores africanos de Peter Brook: a presença extraordinária deles não se acompanhava de um manejo suficiente da língua. Mas, graças a esse obstáculo, Brook queria apresentá-los como sendo atores africanos não integrados, não ocidentalizados, atores vindos de longe e que agregavam, além do papel, informações sobre suas identidades cênicas flutuantes. Não somente a cor da pele, mas também o uso da língua os designava como estrangeiros.

\section{O Corpo Estrangeiro}

No palco, às relações com a língua estrangeira, acrescenta-se frequentemente a relação particular com o corpo estrangeiro. Por vezes, o encenador tem necessidade de utilizá-lo enquanto tal. É um corpo que, explicitamente, afirma uma identidade corporal própria, distinta, um corpo que se mostra como vindo de longe. Isso gera diversos modos de intervenção. O primeiro e o mais evidente consiste em atribuir o personagem 
estrangeiro ao ator estrangeiro, como em $O$ Jardim das cerejeiras encenado por Strehler, no qual o mendigo desconhecido que surge à beira do rio, perturbando a calma precária do interior, é interpretado por um ator russo com um corpo massivo, a voz rouca, verdadeiro protótipo eslavo que destoa do conjunto do elenco. Observa-se com frequência o uso do estrangeiro como um agente perturbador, como um elemento halogênio. Sua principal função é trazer outro corpo, uma outra relação com as palavras, um engajamento e uma presença diferentes. Assim, Claude Régy escalou Milloud Ketib pelas suas raízes berberes e tudo o que elas o permitiam engendrar como poder de deflagração numa cena. Richard Demarcy chamou muitas vezes um ator negro, por razões de plasticidade excepcional, de fluidez, enfim de um verdadeiro swing corporal que se remetia ao universo da comédia musical e a sua dimensão lúdica, preciosos para o encenador. Emiliano Suarez, ator colombiano particularmente pitoresco, na Comédia sem Título de Lorca, numa encenação de Lluis Pasqual, trazia uma presença excessiva, caricatural e, se aproveitando do seu sotaque e do seu corpo, de sua fisionomia, ele tornava surpreendente uma partitura pouco desenvolvida. O corpo estrangeiro intervém como um toque de cor, como uma ruptura, como um choque. E o espetáculo pode tirar proveito ou se prejudicar.

\section{Escalar o Outro}

Antoine Vitez, numa homenagem ao espetáculo de Peter Brook, Les Iks, observava que, pela primeira vez, a escalação dos atores recusava qualquer distinção racial como determinismo imposto pelos dados da situação. $\mathrm{O}$ papel não é mais inacessível a ninguém e todos podem abordá-lo sem a mínima restrição. Tradução generalizada, era assim, aliás, que ele definia o teatro. Aqui, tudo pode se traduzido, e um inglês, um japonês, um negro, uma libanesa, um grego e uma suíça não são impedidos de contar juntos uma história que se passa numa cidadezinha africana. A raça deixa de operar como um critério de escalação. Escalar sem levar em conta a raça do ator e sem considerar que a raça possa produzir

Georges Banu, O Ator Estrangeiro ou o Outro no Teatro.

R.bras.est.pres., Porto Alegre, v.1, n.2, p. 385-403, jul./dez., 2011.

Disponível em http://www.seer.ufrgs.br/presenca 
um significado, que ela possa ser integrada na leitura, é um desafio que acabou se impondo progressivamente. Dessa forma, Deborah Warner emprega um ator negro, tanto em Titus Andronicus quanto em Rei Lear, recusando cada vez a conferir um valor dramatúrgico a negritude; o ator negro se integra no elenco sem a mínima conotação de raça. É a escolha que Vitez reconheceu em Les Iks, de Brook. E que ele adotou quando escolheu um intérprete africano para o cozinheiro holandês de Mãe Coragem. O que antes marcava uma abertura tornou-se agora uma conquista da cena dramática e também da cena lírica.

Brook não trata o estrangeiro como um elemento de ruptura em relação a uma identidade forte, anterior à atuação, identidade do país de acolhimento que se afirma através da maioria do elenco. Não, para Brook, o estrangeiro é um dado geral inicial, pois o objetivo consiste em começar a partir do grupo mais heterogêneo para alcançar, do ponto de vista teatral, o grupo mais organicamente unificado. Para Brook, não é mais o princípio do uno desestabilizado pela presença do Outro que funciona, mas o de um múltiplo inicial que, sem descartar as diferenças, visa a alcançar o uno da equipe. $\mathrm{O}$ trabalho cênico tem um valor unificador.

Brook, em sua viagem a África no início dos anos 1970, escolhe normalmente como espaço de representação a praça ou o mercado. Lá, as pessoas do vilarejo vão mais facilmente, pois, pela sua natureza mesmo, trata-se de um lugar de reunião. Mas a praça pública se define também pelo extraordinário leque de seres e objetos que reúne os indígenas, assim como as pessoas vindas de fora, do exterior do vilarejo. Essa praça, também impura, tem virtudes unificadoras, sem que ela apague, no entanto, as diferenças nem que atenue a multiplicidade. No trabalho de Brook, a utopia comunitária do grupo e o modelo arcaico do mercado heterogêneo se juntam. De um lado a mistura das identidades em nível intercontinental, de outro o recurso aos dados de um território local. Ao reivindicar essa dupla filiação, Brook procura inscrever seu teatro num contexto vital que leva em conta os dados planetários do

Georges Banu, O Ator Estrangeiro ou o Outro no Teatro.

R.bras.est.pres., Porto Alegre, v.1, n.2, p. 385-403, jul./dez., 2011.

Disponível em http://www.seer.ufrgs.br/presenca 
presente, se apoiando, ao mesmo tempo, sobre formas antigas de coexistência.

\section{Trabalhar no Estrangeiro}

Salvo algumas exceções, para o encenador que tem que trabalhar em exílio, o ator do país de acolhimento será quase sempre percebido por ele como decepcionante. O encenador não tem mais seus atores que, intensamente, o permitiram acessar a certa imagem do corpo, na maioria dos casos inencontrável em outro lugar. Perdendo-os, ele lembra o escritor que termina dolorosamente no exílio da sua língua, pois os atores são a língua do encenador. Sem eles, ele tem sempre a sensação de uma falta, a falta de uma realização atingida antes e jamais reconquistada em outro contexto. Durante vinte anos, de Krejca a Lioubimov ou Pintilié, a experiência foi a mesma e provocou a mesma nostalgia. E se hoje eles voltaram aos seus países, é para reencontrar suas línguas, a saber, o ator russo, tcheco ou romeno (isso se explica também pela idade deles e pela sua estética centrada em torno do ator, pois os encenadores latino-americanos chegados mais jovens na França e mais preocupados pela imagem não encontraram as mesmas dificuldades). $O$ trabalho com o ator estrangeiro para os grandes exilados não foi uma escolha, mas um imperativo.

Ao exílio involuntário dos encenadores do antigo Leste, respondem as passagens voluntárias de certos encenadores nos países de acolhimento de sua escolha. Georges Lavaudant, Sophie Loucachevsky, Michel Deutsch, Frédéric Fisbach trabalham seguido em outros lugares. Mas, dessa vez, trata-se de um lapso de tempo bem delimitado, de um exercício que só tem sentido se ele se torna uma experiência passageira alimentada pelo encontro de outro ambiente, de uma outra prática. Nesses casos, Lavaudant insiste, é interessante que, estrangeiro como ele é, ele, ou qualquer outro encenador, aceite se apresentar como um artista que não procura a adaptação, mas a variação, a diferença, a fim de se apresentar melhor como o Outro, aquele que mantém uma relação estranha com o teatro de acolhimento. Apesar disso, para que exista diálogo, é preciso descobrir um terreno comum, um 
consenso mínimo. Não tomar emprestado a estética do local de acolhimento é a razão de ser do estrangeiro de passagem, contudo responder a certos códigos de expectativa é a exigência mesmo de toda troca.

\section{Atuar na sua Língua}

Durante um estágio no Dahomey, apesar da modéstia do texto proposto, Aquele que diz sim, aquele que diz não de Brecht, a qualidade das improvisações ultrapassava de longe a da atuação, sempre um pouco forçada, por vezes simplista ou insistente. Diante das reservas expressadas pelos mestres convidados, ao longo de uma discussão, Din Din, nosso anfitrião, nos ressaltou que para os atores africanos existe sempre o problema da atuação numa língua que não é a deles. Eles atuam numa língua emprestada. Essa observação, particularmente pertinente, será retomada como tema de trabalho pelo professor do estágio Patrick Le Mauff. Ele começará pedindo a cada um dos estagiários para enumerar as línguas que eles conhecem. Eles o fizeram com prazer citando a língua do pai, a língua da mãe e ainda várias outras, eles davam a impressão de querer nos mergulhar em um mundo épico, em uma floresta enleada na qual podemos nos perder sem bússola, labirinto linguístico de uma verdade surpreendente. A África, na riqueza de seus poderes secretos, ressoava pela única declinação de suas línguas que os membros da equipe flexionavam de maneira natural e atentiva. Se alguns falavam línguas que se sobrepunham, outros eram os representantes solitários dessas palavras antigas apegadas a tradições familiares, tribais, enfim, ao mais profundo da memória do corpo. As primeiras tentativas vão revelar explicitamente uma outra qualidade de atuação, um engajamento e uma verdade que se sentia nos cantos, mas nitidamente menos no uso das palavras. Em babouté, em baveck, em fang, em bafia, em gambaye, em crioulo, em bassa, em fon, em árabe, o texto ressoava diferentemente: o ator africano atuava a partir de então com uma precisão que ele não alcançava antes. Patrick Le Mauff comenta: a lógica das ações é o corolário da lógica linguística. Isso me lembra as palavras de Patrice Chéreau que afirma que só se pode ser

Georges Banu, O Ator Estrangeiro ou o Outro no Teatro.

R.bras.est.pres., Porto Alegre, v.1, n.2, p. 385-403, jul./dez., 2011.

Disponível em http://www.seer.ufrgs.br/presenca 
um grande ator atuando na sua língua materna. Luc Bondy concorda, declarando que só se pode atuar ou encenar na língua na qual se sonha. Essa é a razão pela qual o ator europeu, evocado acima, ou o ator africano, encontrado no Dahomey, cada um se alimenta da terra mãe das palavras e da língua de origem. Yoshi Oida não atingiu o ápice de sua presença reencontrando o japonês em Qui est là ou L'homme qui, dois espetáculos de Peter Brook? O que ele traz como estranheza ao país de acolhimento se acompanha de uma perda insuperável, a perda da sua língua. E se ele nos fascina, é como ser duplo, dividido, pois saído da sua língua sem ter chegado realmente na outra. $\mathrm{O}$ exílio torna o ator um inválido da sua língua. Ela continua sendo sua base e seu ponto de retorno.

\section{Atores Vindos de Longe: Sotigui Kouyate e Yoshi Oida}

Sotigui Kouyate foi a grande descoberta africana de Peter Brook. Ele era ator? Certamente não e, no entanto, foi ele que, no palco, respondeu melhor à busca brookiana. A revelação se produziu em Le Mahabharata, em que ele interpretou Bishma, o ser que não podia ser morto e que, entretanto, acaba sendo vencido. Sotigui trazia uma doçura repousante, a doçura do ser reconciliado com ele mesmo e simultaneamente aberto ao desconhecido do mundo. Nós o víamos se deslocar de maneira ao mesmo tempo flexível e desajeitada, pois sua grande altura de antigo jogador de futebol tinha perdido a fluidez de antes, mas, concomitantemente, esse corpo alongado dava provas de uma elegância secreta, de uma nobreza particular, ele era habitado por outra coisa que não o teatro. Os gestos dele são, à primeira vista, elementares, mas, do mesmo modo, eles têm a precisão de uma pintura inocente, pintura das origens, pintura primitiva. Como não ser tocado por essa aparição que se move sobre um palco de teatro como se esse fosse um lugar nobre e pobre? Nenhuma pretensão mística, nenhuma pose filosófica e, no entanto, Sotigui carrega com ele toda essa tradição espiritual da qual ele é o herdeiro e que lhe permite dialogar com os ancestrais e

Georges Banu, O Ator Estrangeiro ou o Outro no Teatro.

R.bras.est.pres., Porto Alegre, v.1, n.2, p. 385-403, jul./dez., 2011.

Disponível em http://www.seer.ufrgs.br/presenca 
questionar a dimensão secreta da vida. Tudo o que ele vê e vive parece estar sob o signo de um lugar distante do qual ele jamais se separa, lugar de uma família e de uma civilização que se encarnam nele. Mas isso não o torna pesado, bem ao contrário, isso o permite adotar uma distância que relativiza os conflitos e conservar esse sorriso interior que é a fonte de sua incomparável doçura. Sotigui, como ator, se inscreve na encenação trazendo, ainda, aquilo do qual ele é digno legatário, aquilo que ele assume e leva com ele. Ele conduz a um além do papel que seduz e fascina. Sotigui trazia ao palco a paz que ia além dos conflitos, ele era um ator insubmisso porque encarregado de uma herança que ele contava respeitar e transmitir. Não uma insubmissão pessoal, mas cultural e espiritual. Isso explica sem dúvidas a atração que ele exercia sobre Peter Brook.

$\mathrm{O}$ outro ator brookiano que pertence a mesma família vem do Japão, Yoshi Oida. Ele, nos seus livros admiráveis, contou sua formação e o afastamento que isso provocou, seu estatuto de ator entre dois mundos e dois modos de ser em cena; Yoshi Oida atuou primeiro em papéis estrangeiros à sua cultura - em Orghast ou Timão de Atenas, em Les Iks ou na Conférence des oiseaux mas sua presença, notou-se, nunca se impôs mais do que quando ele reatou, mesmo que furtivamente, com suas origens orientais. Como se os recursos de uma energia extraordinária adquiridos graças aos exercícios e ao treinamento jorrassem em plena luz. Mahabharata serviu não somente para a descoberta de Sotigui, mas também para a revelação de Yoshi. A África de um lado e o Japão de outro, Bishma e Drona, o general que, encarnado por Yoshi, se constituía numa figura emblemática da honra guerreira. Seu suicídio se remetia à célebre tradição japonesa da morte voluntária que Maurice Pinguet examinou em seu famoso livro. Ele remetia igualmente ao suicídio de seu ídolo, Mishima, a extraordinária tensão do torso nu, a precisão dos gestos, a última dignidade permitia a Yoshi apreender a força mística desse sacrifício habitual na sua cultura de origem. Ela ressurgia nele como uma fonte que nunca seca. Em seguida, a outra vertente - lírica e pacífica - do Japão, lhe permitiu 
alcançar a emoção mais intensa em L'Homme qui quando o doente que ele interpretava se lembrava dos cantos da sua mãe. Cantos dessas mães inteiramente dedicadas aos seus filhos, sacrificadas mesmo por eles, mães cuja lembrança ressuscitava nesse ser com o espírito transtornado que Yoshi interpretava. E como não evocar o brilho do monólogo de Hécuba em Qui est là?, ensaio teatral de Peter Brook em torno de Hamlet, que Yoshi projetava com uma força surpreendente graças também ao mergulho na língua materna, ele, que foi privado de um acesso fácil a outras línguas. Possuidor de uma cultura que ele nunca abandonou ou traiu, Yoshi nunca é melhor do que quando ele a reencontra em ação, no palco. Ele se erige então como ator insubmisso em relação à cultura de acolhimento. Nunca realmente integrado, Yoshi continua um rebelde, nem um pouco explícito, mas implícito. Sua força vem daí.

Sotigui e Yoshi, atores vindos de longe, insubmissos e estrangeiros. Ambos falam de um além do palco que os alimenta e que eles não esquecem.

\footnotetext{
Notas

${ }^{1}$ De antemão, eu reconheço o caráter incompleto e não totalizante desse texto. Eu não posso abraçar nem a totalidade das hipóteses possíveis, nem me basear numa outra bibliografia que não a minha biografia de espectador ou a dos meus amigos, dos meus conhecidos.

${ }^{2}$ N.R.: o autor se refere ao fato de ser estrangeiro, morando e trabalhando na França.

3 Antoine Vitez, Le Cuisinier hollandais, Journal de Chaillot, n. 12, jun. 1983. Vitez aceitava a contradição no seio da qual ele se colocava, contradição entre o teatro conservatório da língua e o teatro laboratório da língua.

${ }^{4}$ Em romeno, Lucien Pinitilié degusta os sotaques, tanto locais quanto estrangeiros, pois ele pode percebê-los, inscrevê-los em um microcosmo cultural, ouvi-los como uma chance dada a sua língua e jamais depositada nele.

5 Como para os escritores, existem exceções também entre os encenadores. Assim, Jacques Lassalle mantém uma relação privilegiada com outro ator norueguês, ator que conjuga, segundo seus mais antigos desejos, a retenção constante e a explosão violenta. Vitez, por sua vez, quando montou no Picolo Teatro de Milano, Le triomphe de l'amour, sentiu um prazer extremo ao encontrar os atores italianos. $\mathrm{O}$ ator estrangeiro é visto então, mas é bem raro, como o corpo incansavelmente procurado: o corpo que o encenador leva com ele e no qual, bruscamente, ele se reconhece.
} 
Georges Banu é ensaísta e crítico teatral. É professor na Université Paris 3 - Sorbonne Nouvelle. Autor de inúmeros livros e ensaios dedicados principalmente aos mais importantes encenadores europeus, ele é notadamente especialista em Peter Brook, ao qual ele consagrou um ensaio chamado Peter Brook, vers un théâtre premier (Seuil, Paris, 2005). Ele é também codiretor da revista Alternatives Théâtrales.

E-mail: georges.banu@univ-paris3.fr

Traduzido do original em francês por Márcio Müller e revisado por Gilberto Icle

Recebido em Julho de 2011

Aceito em Setembro de 2011

Georges Banu, O Ator Estrangeiro ou o Outro no Teatro.

R.bras.est.pres., Porto Alegre, v.1, n.2, p. 385-403, jul./dez., 2011.

Disponível em http://www.seer.ufrgs.br/presenca 